\title{
TWO NEW SPECIES OF THE GENUS CLUBIONA LETRELLIE, 1804 (ARANEAE: CLUBIONIDAE) FROM JAPAN
}

\author{
Toshio HaYashi
}

Hirosawa Elementary School, Hirosawa-cho, Kiryu-shi, Gunma 376, Japan.

\begin{abstract}
Synopsis
Hayashi, Toshio (Hirosawa Elementary School, Hirosawa-cho, Kiryu-shi, Gunma 376, Japan): Two new species of the genus Clubiona Letrellie, 1804 (Araneae: Clubionidae) from Japan. Acta arachnol., 33: 35-43 (1985).

Two new species of the genus Clubiona, C. maikoae and C. akagiensis, are described from Central Japan.
\end{abstract}

Compared with the other families, the Clubionidae has been rather inadequately studied in spite of its importance for understanding the spider fauna of Japan. Since 1940 no one has described new species or revised the previously known species, with the exception of YAGINUMA $(1952,1967,1972,1976)$ and ONO (1975).

Though twenty-five species of the spiders belonging to the genus Clubiona have hitherto been recorded from Japan, some of them were described based only on one sex and some others were known only from the original records made by BöSENBERG and STRAND (1906). It is, therefore, necessary to make a thorough revision of the clubionid spiders.

Since 1979, I have been investigating spiders in the Akagiyama area of Central Japan, and obtained many specimens, among which were included many individuals belonging to the genus Clubiona. As the result of my close examination, it has become apparent that these individuals can be classified into two species, both of which seem to be new to science. In this paper, I am going to describe them under the names of Clubiona maikoaz and C. akagiensis.

The holotypes and some of the paratypes of the species are preserved in the collection of the Arachnolgical Society of East Asia, Ohtemon Gakuin University, Ibaraki, Osaka. The remaining paratypes are preserved in my private collection. 
Before describing the new species, I wish to express my hearty thanks to Dr. Takeo Yaginuma, Ohtemon Gakuin University, for his cordial advice and great help in consulting with important literature. I would also like to thank Mr. Y. Chikuni, who took nice photographs.

\section{Clubiona maikoae n. sp.}

(Japanese name: Maiko-fukurogumo)

(Figs. 1-8)

Female (Holotype): Total length $5.92 \mathrm{~mm}$; carapace $2.80 \mathrm{~mm}$ long, $1.95 \mathrm{~mm}$ wide; abdomen $3.00 \mathrm{~mm}$ long. Eyes ringed with black. Anterior row of eyes narrower than the posterior row in the ratio $3: 4$, almost straight as seen from in front. Posterior row of eyes procurved. AME separated by 1.25 times their diameter, about seven-eights the diameter from ALE. ALE larger than AME. PME separated by about 3.1 times their diameter, about twice the diameter from PLE, nearly equal in size. Order of eyes in diameter, $\mathrm{AME}=\mathrm{PME}=\mathrm{PLE}<\mathrm{ALE}$ $(8: 8: 8: 9)$. MOA wider than long $(41: 28)$, narrower in front than behind $(30: 41)$. Clypeus as high as a half the diameter of AME. Sternum, with hairs toward center, shield-shape, longer than broad (59:38). Labium longer than wide and exceeding half the length of maxillae. Chelicera with seven teeth (two large, others small) on promargin of fang furrow and six teeth on retromargin.
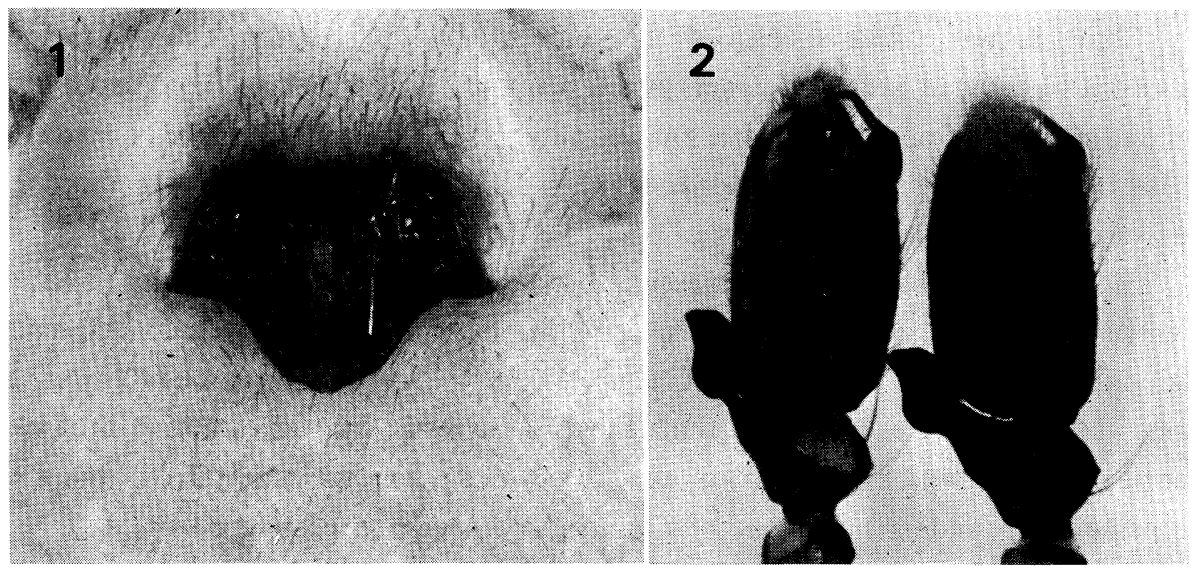

Fig. 1. Clubicna maikoae n. sp., female epigynum, ventral view. (Photograph: Y. CHIKUNI)

Fig. 2. Clubiona maikoae n. sp., male palpus. (Photograph: Y. CHIKUNI) 
Measurements of legs (in $\mathrm{mm}$ ):

\begin{tabular}{cccccc} 
Leg & Fem. & Pat. \& Tib. & Met. & Tar. & Total \\
\hline I & 1.82 & 2.48 & 1.12 & 0.60 & 6.02 \\
II & 1.97 & 2.68 & 1.21 & 0.63 & 6.49 \\
III & 1.78 & 1.90 & 1.51 & 0.60 & 5.79 \\
IV & 2.48 & 2.92 & 2.51 & 0.78 & 8.69 \\
\hline
\end{tabular}

Leg formula 4, 2, 1, 3. Legs with dense claw tufts and short scopulae. Femora I and II with 1-1-2 dorsal spines, femora III and IV with 1-1-3 dorsal spines. Tibiae I and II with 2-2-0 ventral spines and metatarsus I without spine. Metatarsus II with one ventral spine. Tibia III with 1-1 prolateral, 1-1 retrolateral and 1-1 ventral spines. Metatarsus III with 1-2-2 prolateral, 1-0-2 retrolateral and 2-0-2 ventral spines. Tibia IV with 1-1 prolateral, 1-1 retrolateral and 1-1-1 ventral spines. Metatarsus IV with 1-2-2 prolateral, 1-1-2 ret-
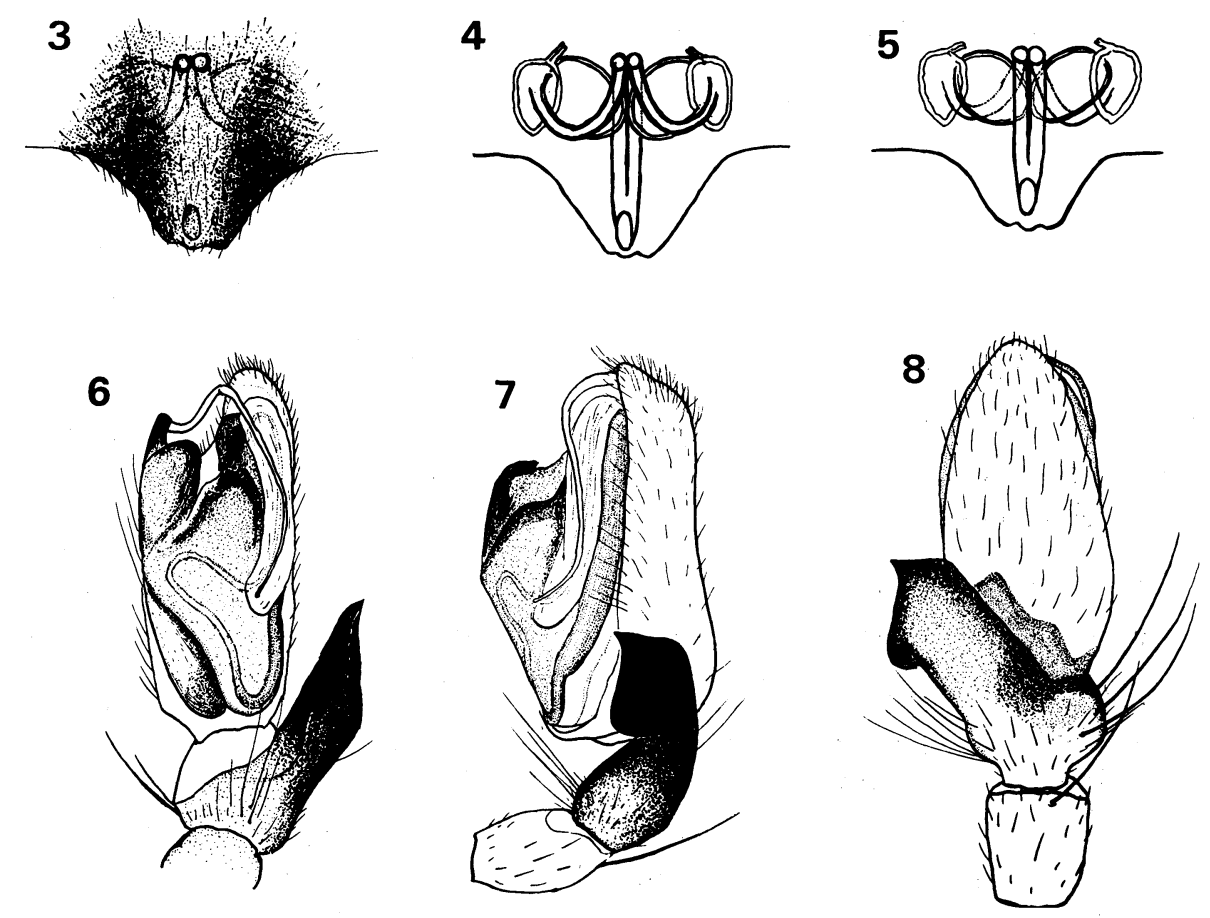

Figs. 3-8. Clubiona maikoae n. sp. 3. Female epigynum, ventral view. 4. Female genitalia, ventral view. 5. Female genitalia, dorsal view. 6. Male palpus, ventral view. 7. Male palpus, retrolateral view. 8. Male palpus, dorsal view. 
rolateral and 2-1-2 ventral spines.

Abdomen oval, with a cluster of long erct setae at anterior end. Posterior spinnerets as long as anteriors but more slender.

Epigynum with a plate projecting posteriorly over genital groove and a copulatory opening (Figs. 1-3). The copulatory tubes conjoin near the copulatory opening and extending anteriorly parallel and close together, then arched laterally. Spermathecae each in two parts, aligned transversely. Interior part oval, larger and more visible than lateral part (Figs. 4-5).

Color: Cephalothorax pale yellowish brown. Chericerae, maxillae and labium yellowish brown. Sternum pale yellow. Abdomen pale reddish brown with complicated patterns. Legs yellowish brown.

Male (Paratype I): Total length $5.21 \mathrm{~mm}$, cephalothorax $2.43 \mathrm{~mm}$ long, 1.95 mm wide; abdomen $2.60 \mathrm{~mm}$ long. General shape and color essentially as in female except the deeper colored abdomen.

Measurements of legs (in $\mathrm{mm}$ ) :

\begin{tabular}{cccccc}
\hline Leg & Fem. & Pat. \& Tib. & Met. & Tar. & Total \\
I & 2.14 & 2.92 & 1.34 & 0.75 & 7.15 \\
II & 2.24 & 3.17 & 1.58 & 0.75 & 7.74 \\
III & 1.82 & 2.21 & 1.46 & 0.60 & 6.09 \\
IV & 2.70 & 3.12 & 2.70 & 0.85 & 9.37 \\
\hline
\end{tabular}

Tibia of palpus with a broad pointed retrolateral apophysis (Fig. 6). Embolus arising at distal end of tegular apophysis, curved around distal end of tegulum, extending basally about two-thirds length of tegulum (Fig. 7). Tegular apophysis long, slender, arising at the middle of tegulur.

Type-series. Holotype: 우, 6-VI-1982, Akagionsen, Miyagi-mura, Seta-gun, Gunma Pref., $1000 \mathrm{~m}$ alt., T. HAyAshi leg. Paratype I: $\hat{\delta}$, same data as holotype. Paratypes: 4 우. same data as holotype; 우 \& $\hat{\delta}, 23-\mathrm{V}-1982$, Akagionsen, T. HAYASH leg.; + , 26-IV-1981, Miyozawa, Miyagi-mura, Seta-gun, Gunma Pref., $700 \mathrm{~m}$ alt., T. HAYASHI leg. ; 우, 7-VIII-1981, Onuma, Akagiyama, Fujimimura, Seta-gun, Gunma Pref., $1400 \mathrm{~m}$ alt., T. HayAshi leg. ; 3우, 25-V-1980, Kamikanbai, Yamada-gun, Gunma Pref., $400 \mathrm{~m}$ alt., T. HAYASHI leg. ; 9 \& $\hat{\delta}$, 5-VII-1981, Konuma, Akagiyama, Fujimi-mura, Seta-gun, Gunma Pref., $1400 \mathrm{~m}$ alt., T. HAYASHI leg.

Other collecting records: 오 24-V-1955, Mt. Bunagatake, Shiga Pref., T. 
Yaginuma leg.; 우, 6-VI-1966, Hienuki, Iwate Pref., S. Kataoka leg.

Remarks: According to the monograph by DoNDALE and REDNER (1976, 1982), the present species belongs to the trivialis group and is very similar to Clubiona hedini Schenkel and $C$. diversa O.P. CAmbridge. However, it is distinguished from them by the following characteristics: Male embolic conductor and tegular apophysis are very long and slender; tibia of palpus bears a broad retrolateral apophysis which curves at right angle; spermathecae are aligned transversely. In this new species, the shape of epigynum resembles that of Clubiona trivialis or $C$. diversa but the genitalia are clearly different in the alignment of spermathecae and the shape of copulatory tubes (Figs. 4-5).

Habitat: Individuals of $C$. maikoae have been collected at elevations between $400 \mathrm{~m}$ and $1,400 \mathrm{~m}$, in the leaf-litter under low shurbs in deciduous forests. Both the sexes were collected from April to July.

Distribution: Japan (Honshu).

\section{Clubiona akagiensis n. sp.}

(Japanese name: Akagi-fukurogumo)

(Figs. 9-15)

Female (Holotype): Total length $7.17 \mathrm{~mm}$ long ; carapace $3.12 \mathrm{~mm}$ long, 2.19 $\mathrm{mm}$ wide; abdomen $4.17 \mathrm{~mm}$ long. Median groove visible as brown linear depression. Abdomen, oval, covered with fine pubescence, with a group of longer setae on dorsum anteriorly. Eyes ringed with black. Anterior row of eyes narrower than posterior row in the ratio $3: 4$, almost straight as seen from in front. Posterior row of eyes procurved. AME separated by their diameter, about the diameter from ALE. PME separated by about 2.5 times their diameter, about 1.8 times the diameter from PLE. Order of eyes in diameter, $\mathrm{AME}=\mathrm{PME}=\mathrm{PLE}$ $<$ ALE $(11: 11: 11: 14)$. MOA wider than long $(53: 36)$, narrower in front than behind (5:8). Clypeus as high as the diameter of AME. Sternum shield-shaped, longer than broad $(65: 44)$, with brown margin. Labium longer than wide, exceeding half the length of maxillae. Chericera with eight teeth (2 large, others small) on promargin of fang furrow, four teeth on retromargin. 
Measurements of legs (in $\mathrm{mm}$ ):

$\begin{array}{cccccc}\text { Leg } & \text { Fem. } & \text { Pat. \& Tib. } & \text { Met. } & \text { Tar. } & \text { Total } \\ \text { I } & 2.14 & 3.07 & 1.34 & 0.85 & 7.40 \\ \text { II } & 2.26 & 3.17 & 1.41 & 0.85 & 7.69 \\ \text { III } & 2.07 & 2.43 & 1.65 & 0.73 & 6.88 \\ \text { VI } & 2.70 & 2.92 & 2.78 & 0.82 & 9.22\end{array}$

Leg formula $4,2,1,3$. Legs with dense claw tufts and short scopulae. Femora I and II with 1-1-2 dorsal spines, femur III with 1-2-3 dorsal spines and femur IV with 1-1-3 dorsal spines. Tibiae I and II with 2-2 ventral spines. Metatarsi I and II with 2 ventral spines. Tibia III with 1-1 prolateral, 1-1 retrolateral and 1-1 ventral spines. Metatarsus III with 1-2-2 prolateral, 1-0-2 retrolateral and 2-0-2 ventral spines. Tibia IV with 1-1 prolateral, 1-1 retrclateral and 1-1-1 ventral spines. Metatarsus IV with 1-2-2 prolateral, 1-1-2 retrolateral and 2-1-2 ventral spines.

Abdomen oval, with some longer setae on dorsum anteriorly. Posterior spinnerets as long as anteriors and slender.

Epigynal plate with a shallow indentation in posterior margin. Copulatory opening slit-like, inconspicuous, located near posterolateral angles of epigynal plate (Fig. 10). Copulatory tubes extending laterally; spermathecae each in two parts, aligned approximately longitudinally, the anterior part larger than the

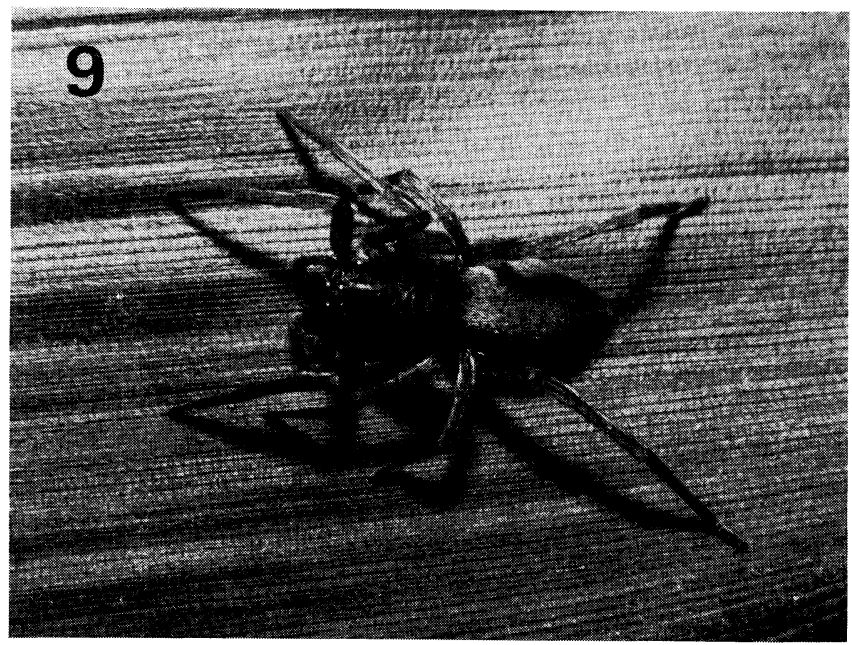

Fig. 9. Clubiona akagiensis n. sp., female. 
posterior part (Fig. 11).

Color: Cephalothorax pale yellowish brown. Chelicerae, maxillae and labium yellowish brown. Sternum pale yellow. Abdomen reddish brown with pattern. Legs pale yellowish brown.

Male (Paratype I): Total length $6.82 \mathrm{~mm}$; cephalothorax $2.80 \mathrm{~mm}$ long, 2.07 $\mathrm{mm}$ wide; abdomen $3.90 \mathrm{~mm}$ long. Cororation and shape similar to those of female.

Measurements of legs (in $\mathrm{mm}$ ):

\begin{tabular}{cccccc} 
Leg & Fem. & Pat. \& Tib. & Met. & Tar. & Total \\
\hline I & 2.51 & 3.34 & 1.70 & 0.97 & 8.52 \\
II & 2.56 & 3.48 & 1.75 & 1.00 & 8.79 \\
III & 2.14 & 2.56 & 2.02 & 0.78 & 7.50 \\
IV & 2.92 & 3.34 & 3.17 & 0.90 & 10.33
\end{tabular}
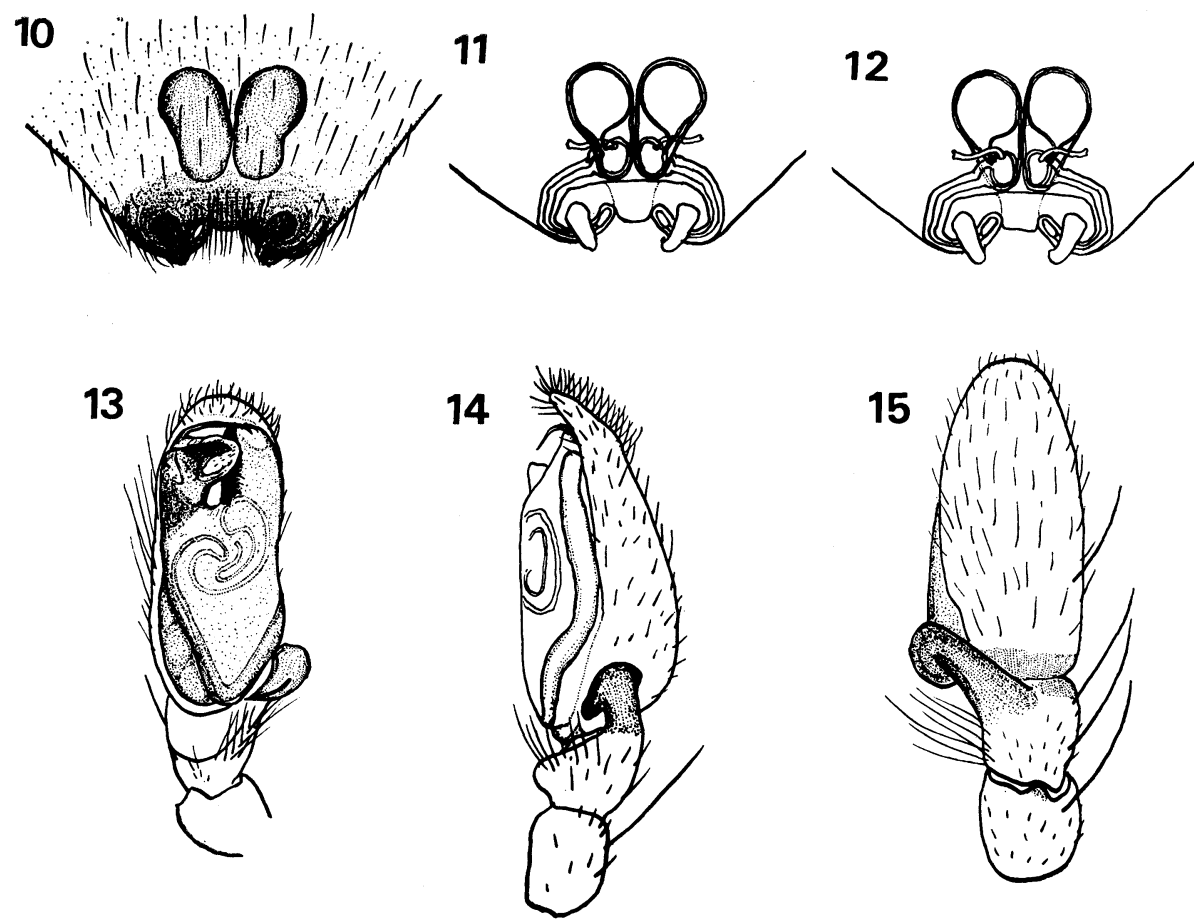

Figs. 10-15. Clubiona akagiensis n. sp. 10. Female epigynum, ventral view. 11. Female genitalia, ventral view. 12. Female genitalia, dorsal view. 13. Male palpus, ventral view. 14. Male palpus, retrolateral view. 15. Male palpus, dorsal view. 
Tibia of palpus with a broad retrolateral apophysis (Fig. 14). Embolus short and slender, tapering toward tip (Fig. 13).

Type-series. Holotype:, , 10-X-1982, Akagiyama, Fujimi-mura, Seta-gun, Gunma Pref., $1300 \mathrm{~m}$ alt., T. HAyAshi leg. Paratype I: $\hat{\delta}$, same data as holotype. Paratypes: 우 \& $\hat{\delta}$, same data as holotype.; 우, 17-IV-1979, Konuma, Akagiyama, Fujimi-mura, Seta-gun, Gunma Pref., $1400 \mathrm{~m}$ alt., T. HAYASHI leg. ; 2ㅇ, 8-VI-1980, Konuma, Akagiyama, $1400 \mathrm{~m}$ alt., T. HAYASHi leg. ; $\uparrow, 5$-VII1980, Konuma, T. Hayashi leg. ; 今, 10-X-1981, Konuma, T. HaYASHi leg. ; 2 , 10-X-1981, Minowa, Fujimi-mura, Seta-gun, Gunma Pref., $1000 \mathrm{~m}$ alt., T. HAYA-

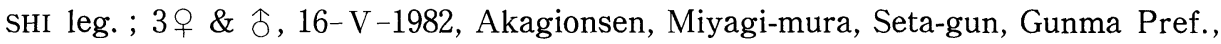
$1100 \mathrm{~m}$ alt., T. HAYASHI leg. ; 우, 4-VIII-1982, Akagiyama, Tone-mura, Tone-gun, Gunma Pref., $1300 \mathrm{~m}$ alt., T. Hayashi leg. ; 우, 4-VII-1982, Kusatsu-machi, Agatsuma-gun, Gunma Pref., $1400 \mathrm{~m}$ alt., T. Hayashi leg.

Remarks: In the palaearctic and nearctic regions, I can't find any species that shows a strong resemblance to the present species.

According to Dondale and Redner $(1976,1982)$, the present species seems to belong to the obesa group, and the epigynum of this new species somewhat resembles those of $C$. obesa Hentz, $C$. mixta Emerton and $C$. lena Bösenberg et STRAND in the shape of spermathecae and copulatory openings. However it differs from the latter three in the following characteristcs: Male embolic conductor is short though very slender; tibia of palpus bears a broad retrolateral apophysis which has not a excavation on dorsal margin; the anterior part of spermathecae is darker than the posterior part.

Habitat: Specimens of $C$. akagiensis have been collected at elevations between $1000 \mathrm{~m}$ and $1400 \mathrm{~m}$, in the leaf-litter under low shrubs in deciduous forests. Both sexes are found from May to October.

Distribution: Japan (Honshu).

\footnotetext{
摘要

林俊夫（桐生市立広沢小学校， $\bar{\top} 376$ 群馬県桐生市広沢町 4-2080)：日本産フクログモ属の 2 新 種。

日本産フクログモ属 Clubiona の 2 新種, Clubiona maikoae (マイコフクログモ) とC. akagiensis（アカギフクログモ）を記載した。
} 


\section{Literature}

Bösenberg, W., \& E. Strrand, 1906. Japanische Spinnen. Abh. Sencken. naturf. Ges., 30 : 93-422, pls. 3-16. Frankfrut.

Dondale, C.D., \& J.H. Redner, 1976. A rearrangement of the north American species of Clubiona, with descriptions of two new species (Araneae: Clubionidae). Cand. Ent., 108 : 1155-1165.

- , \& - 1982. The Insects and Arachnids of Canada. Pt. 9. The Sac Spiders of Canada and Alaska. Agr. Can. Publ. (1724), pp. 1-194.

EDwARD, R. J., 1958. The spider subfamily Clubioninae of United States, Canada and Alaska. Bull. Mus. Comp. Zool., 118 : 365-436.

Locket, G.H., \& A.F. Millidge, 1951. British Spiders. I: 1-294. Ray Society. London. ONo, H., 1975. Spiders from Nikko Region, Tochigi Prefecture. Atypus (64) : 7-26.

Schenkel, E., 1936. Schwedisch-chinisische wissenschaftliche Expedition nach den nordwestlichen provinzen Chinas. Ark. Zool., 29a: 1-314.

Simon, E., 1932. Les Arachnides de France. 6. pt. 4, 773-978.

Son, D., \& Z. Chen, 1979. A new species of spiders of the genus Clubiona (Family Clubionidae) from China. Acta Zootax. sinica., $4: 23-25$.

Tullgren, A., 1946. Svensk Spindelfauna 3 (Clubionidae, Zoridae, Gnaphosidae)-Stockholm. pp. $1-147$.

Wiehle, H., 1965. Die Clubiona-Arten Deutschlands, ihre natürliche Gruppierung und die Einheitlichkeit im Bau ihrer Vulva. Senck. Biol., 46 : 471-505.

Yaginuma, T., 1952. Two new species (Phrurolithus \& Ariamnes) found in Japan. Arachnological News, $1: 13-14$.

- 1967. Revision and new addition to fauna of Japanese spiders, with descriptions of seven new species. Lit. Dept. Rev. Otemon Gakuin Univ., 1: 87-107.

- 1968. Spiders of Japan in colour. pp. i-vii+1-206. pls. 1-56. Hoikusha. Osaka (in Japanese).

- 1972. Spiders of the Hidaka Mauntain Range Hokkaido, Japan. Mem. Natn. Sci. Mus. Tokyo., $5:$ 17-32.

- 1976. Clubiona japonica KARSCH and C. vigil L. Косн. Atypus. (67): 35-37. (in Japanese).

, 1977. A list of Japanese spiders (revised in 1977). Acta arachnol., 27 (Special number) : 367-406. 